\title{
Synthesis, crystal structure and photo-induced DNA cleavage activity of ternary copper(II) complexes of NSO-donor Schiff bases and NN-donor heterocyclic ligands
}

\author{
Shanta Dhar, Munirathinam Nethaji, Akhil R. Chakravarty * \\ Department of Inorganic and Physical Chemistry, Indian Institute of Science, Sir C.V. Raman Avenue, Bangalore 560012, India
}

\begin{abstract}
New ternary copper(II) complexes $\left[\mathrm{CuL}^{n} \mathrm{~B}\right]\left(\mathrm{ClO}_{4}\right)(\mathbf{1}-\mathbf{3})$, where $\mathrm{HL}^{n}$ is the NSO donor Schiff base derived from the condensation of 2-mercaptoethylamine hydrochloride with salicylaldehyde $\left(\mathrm{HL}^{1}\right)$ or 2-hydroxy-3-methoxybenzaldehyde $\left(\mathrm{HL}^{2}\right)$ and $\mathrm{B}$ is $\mathrm{NN}-$ donor heterocyclic base like 2,2'-bipyridine (bpy, 1), 1,10-phenanthroline (phen, 2) or 2,9-dimethyl-1,10-phenanthroline (dmp, 3), are prepared, structurally characterized by X-ray crystallography and their DNA cleavage activity studied. The complexes show distorted square-pyramidal $(4+1) \mathrm{CuN}_{3} \mathrm{OS}$ coordination geometry in which the NSO-donor Schiff base is bonded at the basal plane and the $\mathrm{NN}$-donor heterocyclic base displays axial-equatorial mode of bonding $[\mathrm{Cu}-\mathrm{S}$ distance: $\sim 2.4 \AA]$. The one-electron paramagnetic $\left(\mu_{\mathrm{eff}}=\sim 1.9 \mu_{\mathrm{B}}\right)$ complexes display axial EPR spectra in DMF glass at $77 \mathrm{~K}$ giving $\mathrm{g}_{\|}=\sim 2.2\left(\mathrm{~A}_{\|}=162 \mathrm{G}\right)$ and $\mathrm{g}_{\perp}=\sim 2.0$, indicating $\left\{d_{x^{2}-y^{2}}\right\}^{1}$ ground state. The complexes exhibit visible spectral $\mathrm{d}-\mathrm{d}$ band in MeCN near $650 \mathrm{~nm}$ and two charge transfer bands near $400 \mathrm{~nm}$. Complexes 1 and 2 display quasireversible cyclic voltammetric response in DMF-Tris buffer (1:4 v/v, pH 7.2) for the $\mathrm{Cu}(\mathrm{II}) / \mathrm{Cu}(\mathrm{I})$ couple at ca. $-0.1 \mathrm{~V}$ vs. SCE. Complex 3 exhibits an irreversible reduction process forming $\left[\mathrm{Cu}^{\mathrm{I}}(\mathrm{dmp})_{2}\right]^{+}$. Binding of $\mathbf{1}_{-}$ $\mathbf{3}$ to calf thymus DNA shows the relative order: $\mathbf{2}$ (phen) $\geqslant \mathbf{3}(\mathrm{dmp})>\mathbf{1}$ (bpy). Complex $\mathbf{2}$ efficiently cleaves supercoiled pUC19 DNA in the presence of mercaptopropionic acid (MPA) forming hydroxyl radical or on irradiation with light of 312, 532 and $632.8 \mathrm{~nm}$ wavelength in a type-II process. Complexes $\mathbf{1}$ and $\mathbf{3}$ are cleavage inactive.
\end{abstract}

Keywords: Ternary copper(II) complex; NSO-donor Schiff base; Heterocyclic base; Photo-induced DNA cleavage; Crystal structure

\section{Introduction}

Transition metal complexes that efficiently bind and cleave DNA under physiological conditions have found wide applications in the nucleic acids chemistry as foot printing and sequence specific binding agents, for modeling the restriction enzymes in genomic research, and as new structural probes in diagnostic medicinal applications for the treatment of cancer [1-16]. DNA cleavage reactions generally proceed via

\footnotetext{
* Corresponding author. Tel.: +91 80 22932533; fax: +91 80 23600683.

E-mail address: arc@ipc.iisc.ernet.in (A.R. Chakravarty).
}

two major pathways: (i) oxidative cleavage of DNA involving the sugar and/or guanine base and (ii) hydrolytic pathway involving the phosphate group. Copper complexes are known to be useful reagents for both oxidative and hydrolytic cleavage of DNA [17-40]. Sigman and coworkers [17] have reported bis(phen)copper(I) complex as the first copper-based "chemical nuclease" which cleaves DNA in an oxidative manner in the presence of $\mathrm{H}_{2} \mathrm{O}_{2}$ and a thiol. Subsequent studies have shown that copper-based metallointercalators with redox active metal center are efficient chemical nucleases.

Among several types of DNA cleavage reactions, those occurring under photoactivation are of particular 
importance in highly targeted chemotherapeutic applications. The reagents showing photo-induced DNA cleavage have major advantage over a chemical nuclease as the latter requires a reducing agent and/or $\mathrm{H}_{2} \mathrm{O}_{2}$ for its activity. The reagents cleaving DNA on photoactivation generally show localized effect as they are otherwise nontoxic and such compounds could be useful in the photodynamic therapy (PDT), which has emerged as a promising tool against cancer [41-47]. The FDA approved PDT drug Photophrin ${ }^{\circledR}$, which is a mixture of hematoporphyrin and its derivatives, is currently used for the treatment of lung and esophageal cancers [41]. The drug on photoactivation forms ${ }^{1} \pi \pi^{*}$, which through intersystem crossing generates ${ }^{3} \pi \pi^{*}$ that activates oxygen from its stable triplet $\left({ }^{3} \mathrm{O}_{2}\right)$ to the cytotoxic singlet $\left({ }^{1} \mathrm{O}_{2}\right)$ state in a type-II process. While porphyrin derivatives have largely been used as photosensitizers for PDT applications, copper(II)-porphyrin complexes are known to be inefficient DNA photo-cleavers as the metal significantly reduces the triplet state $\left({ }^{3} \pi \pi^{*}\right)$ lifetime of porphyrin $[12,48]$.

Non-porphyrinic copper(II) complexes showing photo-induced DNA cleavage are rare. Zaleski and coworkers [22] have reported a binary copper(II) complex of 9-diazo-4,5-diazafluorene, which shows photonuclease activity. We have recently shown that copper(II) complexes having dipyridoquinoxaline or NSO-donor Schiff base ligands are efficient photo-cleavers of DNA on visible light irradiation $[30,31,33]$. The present work stems from our interest to explore the DNA cleavage activity of new ternary copper(II) complexes having different heterocyclic ligands and NSOdonor Schiff bases. Herein, we report the synthesis, crystal structure and photonuclease activity of ternary copper(II) complexes of formulation $\left[\mathrm{CuL}^{n} \mathrm{~B}\right]\left(\mathrm{ClO}_{4}\right)$ (1-3), where $\mathrm{HL}^{n}$ is the NSO donor Schiff base derived from the condensation of 2-mercaptoethylamine hydro- chloride with salicylaldehyde $\left(\mathrm{HL}^{1}\right)$ or 2-hydroxy-3methoxybenzaldehyde $\left(\mathrm{HL}^{2}\right)$ and $\mathrm{B}$ is $\mathrm{NN}$-donor heterocyclic base like 2,2'-bipyridine (bpy, 1), 1,10-phenanthroline (phen, 2) or 2,9-dimethyl-1,10-phenanthroline (dmp, 3) (Chart 1). Complex 2 displays efficient photonuclease activity on irradiation with red light.

\section{Experimental}

\subsection{Materials}

All reagents and chemicals of analytical grade were purchased from commercial sources and used without further purification. Solvents were purified by standard procedures [49]. Salicylaldehyde, 2-hydroxy-3-methoxybenzaldehyde, and 2,9-dimethyl-1,10-phenanthroline (dmp) were purchased from Aldrich, USA. Copper(II) acetate $\cdot$ hydrate, 2,2'-bipyridine and 1,10-phenanthroline were purchased from SD Fine Chemicals, Mumbai. 2-Mercaptoethylamine hydrochloride (cysteamine hydrochloride) was procured from Lancaster (UK). The calf thymus DNA, agarose (molecular biology grade), distamycin and ethidium bromide were from Sigma, USA. The supercoiled pUC19 DNA (cesium chloride purified) was purchased from Bangalore Genei (India). Tris- $\mathrm{HCl}$ buffer solution of $\mathrm{pH} 7.2$ was prepared using deionized, sonicated triple distilled water. The Schiff bases $\mathrm{HL}^{1}$ and $\mathrm{HL}^{2}$ were prepared by following a literature method [30].

\subsection{Measurements}

The elemental analysis was done using a PerkinElmer $2400 \mathrm{CHN}$ analyzer. The infrared, electronic, EPR and fluorescence spectral data were recorded using Bruker Equinox 55, Hitachi U-3400, Varian E-109

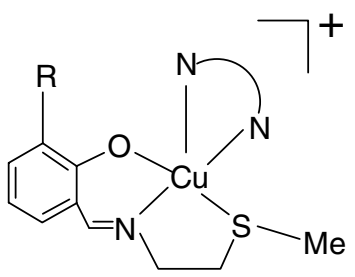

$\left[\mathrm{CuL}^{1}(\mathrm{bpy})\right]\left(\mathrm{ClO}_{4}\right)(\mathbf{1})$

$\left[\mathrm{CuL}^{2}(\right.$ phen $\left.)\right]\left(\mathrm{ClO}_{4}\right)(2)$

$\left[\mathrm{CuL}^{2}(\mathrm{dmp})\right]\left(\mathrm{ClO}_{4}\right)(3)$

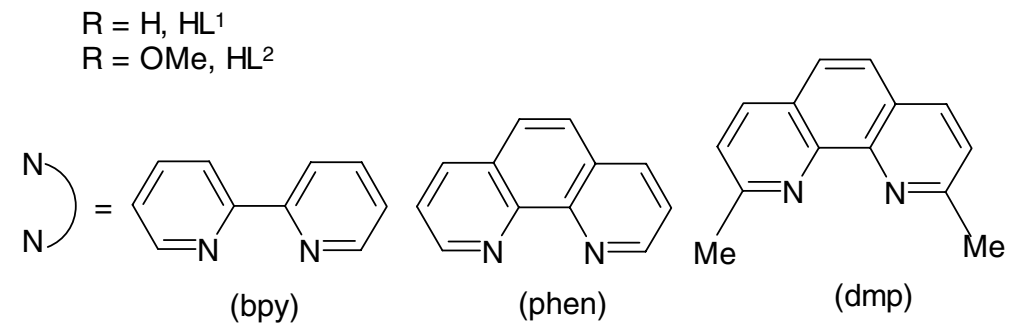

Chart 1. Ligands used and the complexes 1-3. 
X-band, and Perkin-Elmer LS50B spectrometers, respectively. Magnetic susceptibility data were obtained from a model 300 Lewis-coil force magnetometer (George Associates Inc., Berkeley, USA). $\mathrm{Hg}\left[\mathrm{Co}(\mathrm{NCS})_{4}\right]$ was used as a standard. The susceptibility data were corrected for diamagnetic contributions [50]. Electrochemical measurements were done using a three-electrode cell setup comprising a glassy carbon working electrode, a saturated calomel reference electrode and a platinum wire auxiliary electrode on a PAR model 253 Versastat potentiostat/galvanostat with EG \& $G$ electrochemistry softwares. The data were uncorrected for junction potentials. Ferrocene and $\mathrm{K}_{4} \mathrm{Fe}(\mathrm{CN})_{6}$ were used as standards showing the $\mathrm{Fe}(\mathrm{III}) / \mathrm{Fe}(\mathrm{II})$ couple at 0.37 and $0.18 \mathrm{~V}$ vs. SCE, respectively, in MeCN-0.1 M tetrabutylammonium perchlorate (TBAP) and $50 \mathrm{mM}$ Tris- $\mathrm{HCl} / 50 \mathrm{mM} \mathrm{NaCl}$ buffer $(\mathrm{pH} 7.2)$.

\subsection{Synthesis}

Complexes 1-3 were prepared by following a general procedure in which copper(II) acetate $\cdot$ hydrate $(0.5 \mathrm{mmol})$ in $10 \mathrm{ml} \mathrm{MeOH}$ was reacted initially with the heterocyclic base (bpy, phen or dmp, $1.0 \mathrm{mmol}$ ) under magnetic stirring for a period of $30 \mathrm{~min}$ at $25^{\circ} \mathrm{C}$. The resulting solution was then reacted with the Schiff base $\left(\mathrm{HL}^{1}\right.$ or $\left.\mathrm{HL}^{2}, 1.0 \mathrm{mmol}\right)$ taken in $10 \mathrm{ml} \mathrm{MeOH}$. The mixture was stirred for $1 \mathrm{~h}$ at $25^{\circ} \mathrm{C}$, followed by precipitation of the complex as a green solid on addition of a methanolic solution of $\mathrm{NaClO}_{4}$. The solid was isolated, washed with cold methanol and dried in vacuum over $\mathrm{P}_{4} \mathrm{O}_{10}$ (yield: $\sim 65 \%$ ). Anal. Calc. for $\mathrm{C}_{20} \mathrm{H}_{20} \mathrm{~N}_{3} \mathrm{O}_{5} \mathrm{SClCu}(\mathbf{1}): \mathrm{C}, 46.78 ; \mathrm{H}, 3.89 ; \mathrm{N}, 8.19$. Found: C, 46.51; H, 3.98; N, 7.91\%. IR ( $\mathrm{KBr}$ phase, $\mathrm{cm}^{-1}$ ): $3434 \mathrm{w}, 1627 \mathrm{~s}, 1529 \mathrm{w}, 1448 \mathrm{~m}, 1427 \mathrm{~m}, 1317 \mathrm{w}$, $1091 \mathrm{vs}, 849 \mathrm{~m}, 626 \mathrm{~m}$ (vs, very strong; s, strong; m, medium; w, weak). Anal. Calc. for $\mathrm{C}_{23} \mathrm{H}_{22} \mathrm{~N}_{3} \mathrm{O}_{6} \mathrm{SClCu}$ (2): C, 48.64; H, 3.88; N, 7.40. Found: C, 48.45; H, 4.14; N, $7.17 \%$. IR ( $\mathrm{KBr}$ phase, $\mathrm{cm}^{-1}$ ): $3419 \mathrm{w}, 1611 \mathrm{~s}, 1418 \mathrm{~m}$, $1317 \mathrm{w}, 1233 \mathrm{~m}, 1081 \mathrm{vs}, 848 \mathrm{w}, 718 \mathrm{~m}, 617 \mathrm{~m}$. Anal. Calc. for $\mathrm{C}_{25} \mathrm{H}_{26} \mathrm{~N}_{3} \mathrm{O}_{6} \mathrm{SClCu}(3)$ : C, 50.37; H, 4.37; N, 7.03. Found: C, 50.18; H, 4.19; N, 7.21\%. IR ( $\mathrm{KBr}$ phase, $\mathrm{cm}^{-1}$ ): 3413w, 1620s, $1549 \mathrm{~m}, 1421 \mathrm{~m}, 1323 \mathrm{w}, 1081 \mathrm{vs}$, $855 \mathrm{w}, 739 \mathrm{w}, 617 \mathrm{~s}, 480 \mathrm{w}$. The complexes showed stability in the solid state and good solubility in common organic solvents other than hydrocarbons. They were less soluble in water.

Caution! Perchlorate salts of metal complexes are potentially explosive and only small quantities of the complexes 1-3 were handled with care.

\subsection{X-ray crystallography}

Dark-green single crystals of $\left[\mathrm{CuL}^{1}(\mathrm{bpy})\right]\left(\mathrm{ClO}_{4}\right)(\mathbf{1})$ and $\left[\mathrm{CuL}^{2}(\right.$ phen $\left.)\right]\left(\mathrm{ClO}_{4}\right)(2)$ were obtained on slow con- centration of the aqueous methanolic solutions of the complexes. Greenish-brown single crystals of $\left[\mathrm{CuL}^{2}(\mathrm{dmp})\right]\left(\mathrm{ClO}_{4}\right)(3)$ were grown by a diffusion technique in which petroleum ether was layered over a dichloromethane solution of the complex. Crystal mounting was done on glass fibers using epoxy cement. All geometric and intensity data for $\mathbf{1}$ were collected using an automated Enraf-Nonius CAD4 diffractometer equipped with a Mo $\mathrm{K} \alpha$ radiation. Intensity data, collected using $\omega-2 \theta$ scan mode, were corrected for Lorentz-polarization effects and for absorption [51]. The intensity data for $\mathbf{2}$ and $\mathbf{3}$ were obtained from a Bruker SMART APEX CCD diffractometer, equipped with a fine focus $1.75 \mathrm{~kW}$ sealed tube Mo K $\alpha$ X-ray source, with increasing $\omega$ (width of $0.3 \%$ frame) at a scan speed of 8 and $15 \mathrm{~s} /$ frame, respectively. The SMART software was used for data acquisition and the SAINT software for data extraction. Absorption corrections were made using SADABS [52]. The structures were solved and refined with SHELX programs using full-matrix least-squares method [53]. The non-hydrogen atoms were refined anisotropically. The hydrogen atoms of $\mathbf{1}$ and $\mathbf{3}$ were located from the difference Fourier maps and refined isotropically. The hydrogen atoms of $\mathbf{2}$ were fixed in their calculated positions and refined using a riding model. Selected crystallographic data are given in Table 1. Perspective views of the complexes were obtained by ORTEP [54].

\subsection{DNA binding and cleavage experiments}

DNA binding and cleavage experiments were done following the procedures reported earlier [30]. Relative binding of 1-3 to calf thymus (CT) DNA was studied by fluorescence spectral method using the emission properties of ethidium bromide (EB) bound to CT DNA in Tris- $\mathrm{HCl} / \mathrm{NaCl}$ buffer (pH 7.2) [55]. The cleavage of supercoiled (SC) pUC19 DNA $(0.5 \mu \mathrm{g})$ was monitored by agarose gel electrophoresis. The extent of SC DNA cleavage in $50 \mathrm{mM}$ tris-(hydroxymethyl)methane $-\mathrm{HCl}$ (Tris- $\mathrm{HCl}$ ) buffer containing $50 \mathrm{mM} \mathrm{NaCl}$ $(\mathrm{pH}$ 7.2) under dark or illuminated conditions ( $\lambda=312 \mathrm{~nm}, 96 \mathrm{~W}$ as total wattage, UVITEC transilluminator; $532 \mathrm{~nm}, 125 \mathrm{~W}$ mercury vapor lamp; and $632.8 \mathrm{~nm} \mathrm{CW}$ laser of Scientifica-Cook Ltd. make, $3 \mathrm{~mW}$ power) was measured from intensities of the bands stained with EB using UVITEC Gel Documentation system [56].

\section{Results and discussion}

\subsection{Synthesis and crystal structures}

The ternary copper(II) complexes $\mathbf{1}-\mathbf{3}$ are prepared in high yield from a reaction of copper(II) acetate $\cdot$ hydrate with the NN-donor heterocyclic base and the NSO-do- 
Table 1

Crystallographic data for $\left[\mathrm{CuL}^{1}(\mathrm{bpy})\right]\left(\mathrm{ClO}_{4}\right)(\mathbf{1}),\left[\mathrm{CuL}^{2}(\mathrm{phen})\right]\left(\mathrm{ClO}_{4}\right)(\mathbf{2})$ and $\left[\mathrm{CuL}^{2}(\mathrm{dmp})\right]\left(\mathrm{ClO}_{4}\right)(\mathbf{3})$

\begin{tabular}{|c|c|c|c|}
\hline & Complex 1 & Complex 2 & Complex 3 \\
\hline Formula & $\mathrm{C}_{20} \mathrm{H}_{20} \mathrm{CuClSN}_{3} \mathrm{O}_{5}$ & $\mathrm{C}_{23} \mathrm{H}_{22} \mathrm{CuClSN}_{3} \mathrm{O}_{6}$ & $\mathrm{C}_{25} \mathrm{H}_{26} \mathrm{CuClSN}_{3} \mathrm{O}_{6}$ \\
\hline Formula weight $\left(\mathrm{g} \mathrm{M}^{-1}\right)$ & 513.44 & 567.49 & 595.54 \\
\hline Space group & $P \overline{1}$ & $P 2_{1} 2_{1} 2_{1}$ & $P 2_{1} / c$ \\
\hline$a(\AA)$ & $7.7157(14)$ & $7.7414(16)$ & $11.866(6)$ \\
\hline$b(\AA)$ & $11.7902(11)$ & $22.621(5)$ & $8.499(4)$ \\
\hline$c(\AA)$ & $11.8573(17)$ & $27.399(6)$ & $25.572(12)$ \\
\hline$\alpha\left({ }^{\circ}\right)$ & $84.245(16)$ & 90.0 & 90.0 \\
\hline$\beta\left({ }^{\circ}\right)$ & $83.535(13)$ & 90.0 & $93.587(8)$ \\
\hline$\gamma\left({ }^{\circ}\right)$ & $80.177(18)$ & 90.0 & 90.0 \\
\hline$V\left(\AA^{3}\right)$ & $1052.5(3)$ & $4798(17)$ & $2574(2)$ \\
\hline$Z$ & 2 & 8 & 4 \\
\hline$T(\mathrm{~K})$ & 293(2) & 293(2) & 293(2) \\
\hline Density (calculated) $\left(\mathrm{Mg} / \mathrm{m}^{3}\right)$ & 1.620 & 1.571 & 1.537 \\
\hline$\lambda(\AA)($ Mo K $\alpha)$ & 0.71073 & 0.71073 & 0.71073 \\
\hline Absorption coefficient $\left(\mathrm{mm}^{-1}\right)$ & 1.302 & 1.154 & 1.080 \\
\hline Crystal size $\left(\mathrm{mm}^{3}\right)$ & $0.43 \times 0.40 \times 0.20$ & $0.39 \times 0.35 \times 0.18$ & $0.45 \times 0.35 \times 0.30$ \\
\hline Data/restraints/parameters & $3685 / 0 / 360$ & $9385 / 0 / 631$ & $5068 / 0 / 438$ \\
\hline Goodness-of-fit on $F^{2}$ & 1.134 & 1.098 & 0.972 \\
\hline$R\left(F_{\mathrm{o}}\right)^{\mathrm{a}}[I>2 \sigma(I)]$ & 0.0378 & 0.0634 & 0.0368 \\
\hline$w R\left(F_{\mathrm{o}}\right)^{\mathrm{b}}(I>2 \sigma(I))$ & 0.1198 & 0.1277 & 0.0822 \\
\hline$R$ (all data) & 0.0456 & 0.0887 & 0.0535 \\
\hline$w R$ (all data) & 0.1256 & 0.1374 & 0.0879 \\
\hline Largest differential peak and hole $\left(\mathrm{e} \AA^{-3}\right)$ & 0.569 & 0.579 & 0.344 \\
\hline Weight factor: $w=1 /\left[\sigma^{2}\left(F_{\mathrm{o}}^{2}\right)+(a P)^{2}+(b P)\right]$ & $A=0.0820, B=0.4163$ & $A=0.0648, B=0.0000$ & $A=0.0433, B=0.0000$ \\
\hline
\end{tabular}

nor Schiff base in methanol and isolated as perchlorate salts. We have used three heterocyclic bases having different planarity. While the metal-bpy moiety is not an effective metallointercalator, the copper-phen and copper-dmp moieties are expected to show good DNA binding property. Again, the dmp ligand with two methyl substituents could display significantly different DNA binding and cleavage properties in comparison to its phen analog in a ternary structure. The complexes are characterized from their analytical and physicochemical data (Table 2). The one-electron paramagnetic complexes display axial X-band EPR spectral features that are characteristic for an essentially square pyramidal geometry giving $\mathrm{g}_{\|}$and $\mathrm{g}_{\perp}$ values of $\sim 2.2\left(\mathrm{~A}_{\|}=162 \mathrm{G}\right)$ and $\sim 2.0$, respectively, in DMF glass at $77 \mathrm{~K}$. The electronic spectra of the complexes in $\mathrm{MeCN}$ exhibit a broad $\mathrm{d}-\mathrm{d}$ band near $650 \mathrm{~nm}$ and a charge transfer (CT) band near $400 \mathrm{~nm}$. Complexes 1 and 2 show quasi-reversible cyclic voltammetric response for the $\mathrm{Cu}(\mathrm{II}) / \mathrm{Cu}(\mathrm{I})$ couple near $0.0 \mathrm{~V}$ vs. SCE in DMF-Tris$\mathrm{HCl} / 0.1 \mathrm{M} \mathrm{KCl}$ buffer $(1: 4 \mathrm{v} / \mathrm{v}, \mathrm{pH}=7.2)$ with an anodic to cathodic peak current ratio $\left(i_{\mathrm{pa}} / i_{\mathrm{pc}}\right)$ of unity at different scan rates. In an aprotic solvent like $\mathrm{CH}_{2} \mathrm{Cl}_{2}$, the redox process is irreversible showing a large separation between the cathodic and anodic peaks with a poor anodic response. The observed reversibility of the redox process in the buffer medium could be due to the presence of an electroprotic reaction that stabilizes the four coordinate structure of the copper(I) species:
$\left[\mathrm{Cu}^{\mathrm{II}} \mathrm{L}^{n} \mathrm{~B}\right]^{+}+\mathrm{H}^{+}+\mathrm{e}^{-} \rightleftharpoons\left[\mathrm{Cu}^{\mathrm{I}}\left(\mathrm{HL}^{n}\right) \mathrm{B}\right]^{+}$. The phenolate oxygen is likely to get protonated in this reaction. Complex 3 in both aqueous and non-aqueous solvents shows a cathodic peak with a weak anodic counterpart. The reduced ternary complex $\left[\mathrm{Cu}^{\mathrm{I}} \mathrm{L}^{2}(\mathrm{dmp})\right]$ seems to form stable $\left[\mathrm{Cu}(\mathrm{dmp})_{2}\right]^{+}$during the voltammetric scan and the observed anodic peak position corresponds well to this binary species in solution [57].

Complexes 1-3 are structurally characterized by single crystal X-ray crystallography. The crystal structures show the presence of cationic copper(II) complex with lattice perchlorate anion. Selected bond parameters are given in Table 3. The ORTEP views are shown in Figs. $1-3$. The copper atom in the ternary structures is bonded to a NSO-donor Schiff base and a NN-donor heterocyclic base giving a distorted square pyramidal $(4+1) \mathrm{Cu}-$ $\mathrm{N}_{3} \mathrm{OS}$ coordination geometry. The trigonality parameter $(\tau)$ values are 0.34 for $\mathbf{1}, 0.2$ and 0.1 for two independent molecules in the asymmetric unit of $\mathbf{2}$, and 0.1 for 3 [58]. The mono-anionic Schiff base binds at the basal plane. The heterocyclic base displays axial-equatorial mode of bonding. The average $\mathrm{Cu}-\mathrm{O}$ and $\mathrm{Cu}-\mathrm{S}$ bond distances are 1.92 and $2.41 \AA$, respectively. The $\mathrm{Cu}-\mathrm{N}$ axial bond distance shows significant variation. The steric effect of the methoxy group of the Schiff base and the methyl groups in dmp is apparent from the significant elongation of the axial $\mathrm{Cu}-\mathrm{N}$ bond length giving the order: $\mathbf{3}>\mathbf{2}>\mathbf{1}$. The $\mathrm{Cu}-\mathrm{N}$ bond involving the imine moiety of the Schiff base is shorter than the basal $\mathrm{Cu}-\mathrm{N}$ 
Table 2

Physicochemical data on $\left[\mathrm{CuL}^{1}(\mathrm{bpy})\right]\left(\mathrm{ClO}_{4}\right)(\mathbf{1}),\left[\mathrm{CuL}^{2}(\mathrm{phen})\right]\left(\mathrm{ClO}_{4}\right)(\mathbf{2})$ and $\left[\mathrm{CuL}^{2}(\mathrm{dmp})\right]\left(\mathrm{ClO}_{4}\right)(\mathbf{3})$

\begin{tabular}{|c|c|c|c|c|c|c|c|c|}
\hline \multirow[t]{2}{*}{ No. } & \multirow[t]{2}{*}{ Complex } & \multirow[t]{2}{*}{$\mathrm{IR}^{\mathrm{a}}, \mathrm{cm}^{-1} v\left(\mathrm{ClO}_{4}\right)$} & \multicolumn{2}{|c|}{$\lambda, \mathrm{nm}\left(\varepsilon, \mathrm{M}^{-1} \mathrm{~cm}^{-1}\right)^{\mathrm{b}}$} & \multirow[t]{2}{*}{$E_{1 / 2}, \mathrm{~V}\left(\Delta E_{p}, \mathrm{mV}\right)^{\mathrm{c}}$} & \multicolumn{2}{|l|}{$\mathrm{EPR}^{\mathrm{d}}$} & \multirow[t]{2}{*}{$\mu_{\text {eff }}\left(\mu_{\mathrm{B}}\right)^{\mathrm{C}}$} \\
\hline & & & $\mathrm{d}-\mathrm{d}$ & $\mathrm{CT}$ & & $\mathrm{g}_{\|}\left(\mathrm{A}_{\|}, \mathrm{G}\right)$ & $\mathrm{g}_{\perp}$ & \\
\hline 1. & {$\left[\mathrm{Cu}\left(\mathrm{L}^{1}\right)(\mathrm{bpy})\right]\left(\mathrm{ClO}_{4}\right)(\mathbf{1})$} & 1091 & $662(280)$ & $401(1980),{ }^{\mathrm{f}} 376(2300)$ & $-0.18(290)$ & $2.21(150)$ & 2.00 & 1.87 \\
\hline 2. & {$\left[\mathrm{Cu}\left(\mathrm{L}^{2}\right)(\mathrm{phen})\right]\left(\mathrm{ClO}_{4}\right)(\mathbf{2})$} & 1081 & $652(140)$ & 385 (2230), $328(3800)$ & $-0.06(120)$ & $2.15(140)$ & 1.99 & 1.93 \\
\hline 3. & {$\left[\mathrm{Cu}\left(\mathrm{L}^{2}\right)(\mathrm{dmp})\right]\left(\mathrm{ClO}_{4}\right)(\mathbf{3})$} & 1081 & $634(170)$ & 452 (1640), 379 (3870) & $-0.45,^{\mathrm{g}}-0.03^{\mathrm{h}}$ & $2.24(175)$ & 2.02 & 1.89 \\
\hline \\
\hline \multicolumn{9}{|c|}{ b In MeCN. } \\
\hline \multicolumn{9}{|c|}{${ }^{\mathrm{c}}$ Corresponds to $\mathrm{Cu}(\mathrm{II}) / \mathrm{Cu}(\mathrm{I})$ couple at scan rate $50 \mathrm{mV} \mathrm{s}^{-1}$ in DMF-Tris-buffer $(1: 4 \mathrm{v} / \mathrm{v}) / 0.1 \mathrm{M} \mathrm{KCl} . \mathrm{E}_{1 / 2}=0.5\left(E_{\mathrm{pa}}+E_{\mathrm{pc}}\right) . \Delta E_{\mathrm{p}}=E_{\mathrm{pa}}-E_{\mathrm{pc}}$, } \\
\hline \multicolumn{9}{|c|}{ where $E_{\mathrm{pa}}$ and $E_{\mathrm{pc}}$ are anodic and cathodic peak potentials, respectively. } \\
\hline \multirow{2}{*}{\multicolumn{9}{|c|}{$\begin{array}{l}\text { d In DMF-glass at } 77 \mathrm{~K} . \\
\text { e } 298 \mathrm{~K}\end{array}$}} \\
\hline & & & & & & & & \\
\hline \multicolumn{3}{|c|}{${ }^{\mathrm{f}}$ Additional broad peak near $476 \mathrm{~nm}\left(\varepsilon, \sim 200 \mathrm{M}^{-1} \mathrm{~cm}^{-1}\right)$. } & & & & & & \\
\hline \multicolumn{9}{|c|}{$\mathrm{g}$ Broad $E_{\mathrm{pc}}$} \\
\hline & & & & & & & & \\
\hline
\end{tabular}

Table 3

Selected bond distances $(\AA)$ and angles $\left(^{\circ}\right)$ for $\left[\mathrm{CuL}^{1}(\mathrm{bpy})\right]\left(\mathrm{ClO}_{4}\right)(\mathbf{1})$, $\left[\mathrm{CuL}^{2}(\mathrm{phen})\right]\left(\mathrm{ClO}_{4}\right)$ (2) and $\left[\mathrm{CuL}^{2}(\mathrm{dmp})\right]\left(\mathrm{ClO}_{4}\right)$ (3) with estimated standard deviations in their parentheses

\begin{tabular}{lccc}
\hline & Complex 1 & Complex 2 & Complex 3 \\
\hline $\mathrm{Cu}(1)-\mathrm{O}(1)$ & $1.916(2)$ & $1.934(4)$ & $1.9144(18)$ \\
$\mathrm{Cu}(1)-\mathrm{N}(1)$ & $2.185(3)$ & $2.227(4)$ & $2.245(2)$ \\
$\mathrm{Cu}(1)-\mathrm{N}(2)$ & $2.013(3)$ & $2.028(4)$ & $2.040(2)$ \\
$\mathrm{Cu}(1)-\mathrm{N}(3)$ & $1.935(3)$ & $1.941(4)$ & $1.939(2)$ \\
$\mathrm{Cu}(1)-\mathrm{S}(1)$ & $2.4091(10)$ & $2.3983(18)$ & $2.4104(12)$ \\
$\mathrm{Cu}(2)-\mathrm{O}(3)$ & - & $1.923(4)$ & - \\
$\mathrm{Cu}(2)-\mathrm{N}(4)$ & - & $2.222(5)$ & - \\
$\mathrm{Cu}(2)-\mathrm{N}(5)$ & - & $2.023(4)$ & - \\
$\mathrm{Cu}(2)-\mathrm{N}(6)$ & - & $1.947(5)$ & - \\
$\mathrm{Cu}(2)-\mathrm{S}(2)$ & - & $2.432(2)$ & - \\
$\mathrm{O}(1)-\mathrm{Cu}(1)-\mathrm{N}(1)$ & $104.02(10)$ & $102.30(17)$ & $92.66(8)$ \\
$\mathrm{O}(1)-\mathrm{Cu}(1)-\mathrm{N}(2)$ & $89.09(10)$ & $87.45(16)$ & $89.89(8)$ \\
$\mathrm{O}(1)-\mathrm{Cu}(1)-\mathrm{N}(3)$ & $94.31(11)$ & $93.73(17)$ & $94.09(8)$ \\
$\mathrm{O}(1)-\mathrm{Cu}(1)-\mathrm{S}(1)$ & $152.73(8)$ & $152.76(12)$ & $169.24(6)$ \\
$\mathrm{N}(1)-\mathrm{Cu}(1)-\mathrm{N}(2)$ & $78.09(11)$ & $78.51(18)$ & $78.24(8)$ \\
$\mathrm{N}(1)-\mathrm{Cu}(1)-\mathrm{N}(3)$ & $102.51(11)$ & $104.19(18)$ & $116.69(8)$ \\
$\mathrm{N}(1)-\mathrm{Cu}(1)-\mathrm{S}(1)$ & $102.57(8)$ & $104.34(13)$ & $97.22(6)$ \\
$\mathrm{N}(2)-\mathrm{Cu}(1)-\mathrm{N}(3)$ & $176.28(11)$ & $176.7(2)$ & $164.28(9)$ \\
$\mathrm{N}(2)-\mathrm{Cu}(1)-\mathrm{S}(1)$ & $90.55(8)$ & $92.34(14)$ & $87.96(6)$ \\
$\mathrm{N}(3)-\mathrm{Cu}(1)-\mathrm{S}(1)$ & $85.74(9)$ & $85.22(15)$ & $85.30(7)$ \\
$\mathrm{O}(3)-\mathrm{Cu}(2)-\mathrm{N}(6)$ & - & $93.6(2)$ & - \\
$\mathrm{O}(3)-\mathrm{Cu}(2)-\mathrm{N}(5)$ & - & $87.98(19)$ & - \\
$\mathrm{N}(6)-\mathrm{Cu}(2)-\mathrm{N}(5)$ & - & $175.3(2)$ & - \\
$\mathrm{O}(3)-\mathrm{Cu}(2)-\mathrm{N}(4)$ & - & $103.2(2)$ & - \\
$\mathrm{N}(6)-\mathrm{Cu}(2)-\mathrm{N}(4)$ & - & $104.5(2)$ & - \\
$\mathrm{N}(5)-\mathrm{Cu}(2)-\mathrm{N}(4)$ & - & $79.4(2)$ & - \\
$\mathrm{O}(3)-\mathrm{Cu}(2)-\mathrm{S}(2)$ & - & $158.40(16)$ & - \\
$\mathrm{N}(6)-\mathrm{Cu}(2)-\mathrm{S}(2)$ & - & $85.56(16)$ & - \\
$\mathrm{N}(5)-\mathrm{Cu}(2)-\mathrm{S}(2)$ & - & $91.33(15)$ & - \\
$\mathrm{N}(4)-\mathrm{Cu}(2)-\mathrm{S}(2)$ & - & $97.90(15)$ & - \\
\hline & & & \\
\hline
\end{tabular}

(heterocyclic base) distance. The dihedral angles between the mean planes of the five and six member chelate rings of the Schiff bases in 1-3 range within 15-32 .

\subsection{DNA binding and cleavage activity}

Fluorescence spectral technique using the emission intensity of ethidium bromide (EB) bound to calf thy-

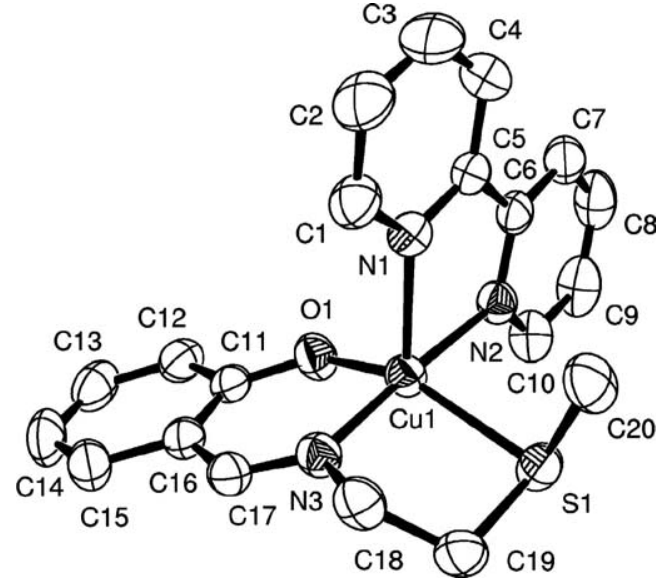

Fig. 1. ORTEP view of the cationic complex in $\left[\mathrm{CuL}^{1}(\mathrm{bpy})\right]\left(\mathrm{ClO}_{4}\right)(\mathbf{1})$ with atom numbering scheme and $50 \%$ probability thermal ellipsoids.

mus DNA has been used to determine the binding propensity of 1-3. Complex $\left[\mathrm{Cu}(\text { phen })_{2}\left(\mathrm{H}_{2} \mathrm{O}\right)\right]^{2+}$ is used as a standard. EB does not show any emission in the Tris buffer medium due to fluorescence quenching of the free EB by the solvent molecules [59]. In the presence of CT DNA, it shows enhanced emission intensity due to binding of EB to DNA. A competitive binding of the complex results in the decrease in the emission intensity, either due to displacement of bound EB by the complex or by quenching of the emission in the presence of the copper(II) complex. The binding order observed is: $\left[\mathrm{Cu}(\text { phen })_{2}\left(\mathrm{H}_{2} \mathrm{O}\right)\right]^{2+} \gg \mathbf{2} \geqslant \mathbf{3}>\mathbf{1}$. The bpy complex is a poor binder to DNA. The phen and dmp ligands having planar structures show good DNA binding ability giving a $K_{\text {app }}$ value of $8.5 \times 10^{5} \mathrm{M}^{-1}$ for $2\left[K_{\text {app }}\right.$ (EB) $=10^{7} \mathrm{M}^{-1}$ ] [59]. The DNA cleavage activity of the complexes has been studied in the presence of mercaptopropionic acid (MPA) as a reducing agent (Fig. 4(a)). Selected cleavage data are given in Table 4 . The bpy and dmp complexes do not show any significant cleavage of supercoiled pUC19 DNA in the presence of MPA. The phen complex 2, however, efficiently cleaves SC DNA 

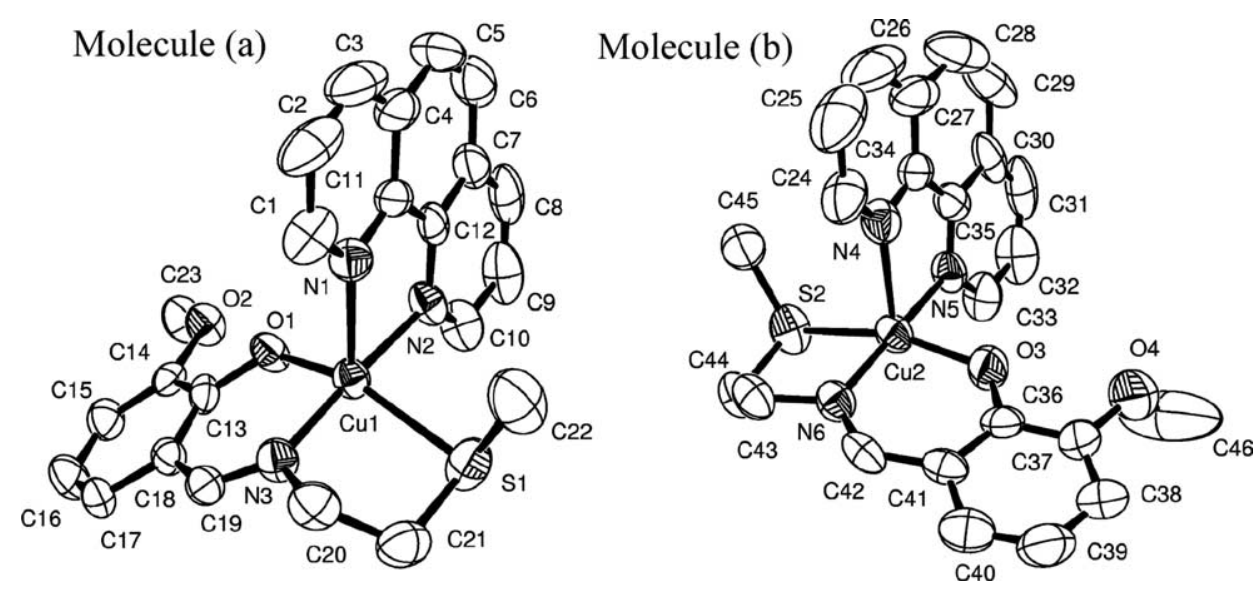

Fig. 2. ORTEP view of the cationic complex in $\left[\mathrm{CuL}^{2}(\mathrm{phen})\right]\left(\mathrm{ClO}_{4}\right)(2)$ with atom labeling scheme and $50 \%$ probability thermal ellipsoids. The crystallographic asymmetric unit contains two independent molecules of $\mathbf{2}$.

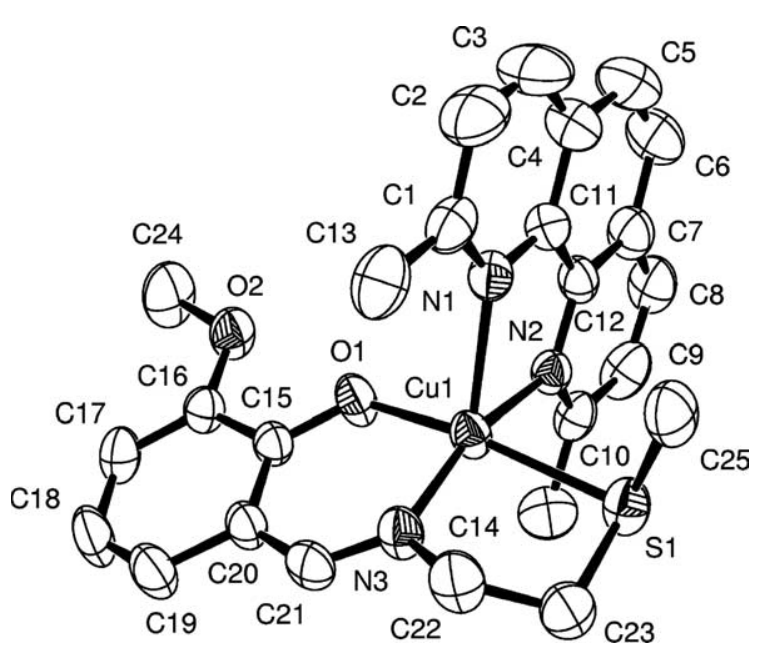

Fig. 3. ORTEP view of the cationic complex in $\left[\mathrm{CuL}^{2}(\mathrm{dmp})\right]\left(\mathrm{ClO}_{4}\right)(\mathbf{3})$ showing atom numbering scheme and $50 \%$ probability thermal ellipsoids.

when treated with MPA. Control experiments indicate the formation of hydroxyl radical and/or copper-oxo species as the cleavage active species [21]. Control experiments using $\mathbf{2}$ have shown the inhibition of cleavage in the presence of hydroxyl radical scavenger like DMSO or mannitol. Complex 2 binds DNA in the minor groove as distamycin inhibits the DNA cleavage. The mechanistic pathways involved are believed to be similar to those reported by Sigman and coworkers [6,7] for the "chemical nuclease" activity of bis(phen)copper species.

The photo-induced DNA cleavage activity of the complexes in the absence of MPA has been studied using UV and visible lights of different wavelengths. The bpy complex is cleavage inactive. The phen and dmp complexes of $80 \mu \mathrm{M}$ concentration cleave SC pUC19 DNA $(0.5 \mu \mathrm{g})$ to the extent of $73 \%$ and $18 \%$, respectively, for an exposure of $10 \mathrm{~min}$ at $312 \mathrm{~nm}$ (Fig. 4(b)). Control experiments show that the bis(phen)copper(II) species

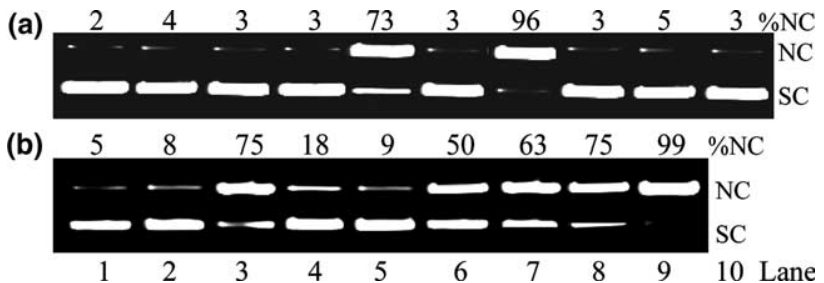

Fig. 4. (a) Cleavage of supercoiled pUC19 DNA $(0.5 \mu \mathrm{g})$ by $\mathbf{1}-\mathbf{3}$ $(40 \mu \mathrm{M})$ and $\left[\mathrm{Cu}(\text { phen })_{2}\left(\mathrm{H}_{2} \mathrm{O}\right)\right]\left(\mathrm{ClO}_{4}\right)_{2}(40 \mu \mathrm{M})$ in the presence of 3mercaptopropionic acid (MPA, $5 \mathrm{mM})$ under dark $(15 \mathrm{~min}$ reaction time): lane 1, DNA control; lane 2, DNA + MPA; lane 3, DNA + 2, lane 4, DNA + 1 + MPA; lane 5, DNA + 2 + MPA; lane 6, DNA + 3 + MPA; lane 7, DNA + [Cu(phen $\left.)_{2}\left(\mathrm{H}_{2} \mathrm{O}\right)\right]\left(\mathrm{ClO}_{4}\right)_{2}+\mathrm{MPA}$; lane 8 , DNA + DMSO $(2 \mu \mathrm{l})+\mathbf{2}+\mathrm{MPA}$; lane 9, DNA + mannitol $(2 \mu \mathrm{l})+\mathbf{2}+\mathrm{MPA}$; lane 10 , DNA + distamycin $(90 \mu \mathrm{M})+\mathbf{2}+\mathrm{MPA}$. (b) Photocleavage of SC pUC19 DNA $(0.5 \mu \mathrm{g})$ by $\mathbf{1}-\mathbf{3}$ at different complex concentrations and exposure times using monochromatic radiations of wavelength $312 \mathrm{~nm}$ : lane 1, DNA control (25 min); lane 2 , DNA + $1(80 \mu \mathrm{M}, 10 \mathrm{~min})$; lane 3, DNA + $2(80 \mu \mathrm{M}, 10 \mathrm{~min})$; lane $4, \mathrm{DNA}+3(80 \mu \mathrm{M}, 10 \mathrm{~min}) ;$ lane $5, \mathrm{DNA}+\left[\mathrm{Cu}(\text { phen })_{2}\left(\mathrm{H}_{2} \mathrm{O}\right)\right]$ $\left(\mathrm{ClO}_{4}\right)_{2}(80 \mu \mathrm{l}, 10 \mathrm{~min})$; lane $6, \mathrm{DNA}+\mathbf{2}(50 \mu \mathrm{M}, 10 \mathrm{~min})$; lane 7 , $\mathrm{DNA}+2(50 \mu \mathrm{M}, 15 \mathrm{~min}) ;$ lane $8, \mathrm{DNA}+2(50 \mu \mathrm{M}, 20 \mathrm{~min})$; lane 9, $\mathrm{DNA}+2(50 \mu \mathrm{M}, 25 \mathrm{~min})$.

is inactive under similar reaction conditions. Complex 2 also cleaves SC DNA on irradiation with visible lights of 532 and $632.8 \mathrm{~nm}$ (Fig. 5(a)). The DNA cleavage activity of $\mathbf{2}$ is found to be less than that of its analog $\left[\mathrm{CuL}^{1}\right.$ (phen) $]\left(\mathrm{ClO}_{4}\right)[30,31]$. The steric bulk of $\mathrm{HL}^{2}$ containing the methoxy substituent could reduce the cleavage activity of the complex due to its lower DNA binding property. We have probed the DNA cleavage reactions using several reagents in control experiments at $532 \mathrm{~nm}$ (Fig. 5(b)). The phen complex is inactive under argon and shows enhancement of DNA cleavage in $\mathrm{D}_{2} \mathrm{O}$. This suggests the possibility of having singlet oxygen as the reactive species. Addition of azide ion inhibits the cleavage, while DMSO, ethanol and mannitol show no apparent effect on the cleavage efficiency. In the 
Table 4

Selected data ${ }^{\mathrm{a}}$ for the cleavage of SC pUC19 DNA $(0.5 \mu \mathrm{g})$ by the complexes $\left.\left[\mathrm{CuL}^{1}(\mathrm{bpy})\right]\left(\mathrm{ClO}_{4}\right)(\mathbf{1}),\left[\mathrm{CuL}^{2}\left(\mathrm{phen}^{2}\right)\right]\left(\mathrm{ClO}_{4}\right)(\mathbf{2}) \mathrm{and}^{2} \mathrm{CuL}^{2}\left(\mathrm{dmp}^{2}\right)\right]\left(\mathrm{ClO}_{4}\right)$ (3) in the presence of mercaptopropionic acid (MPA) or on photo-irradiation

\begin{tabular}{|c|c|c|c|c|c|c|}
\hline Sl. No. & Reaction condition & Complex $(\mu \mathrm{M})$ & $\lambda(\mathrm{nm})$ & $t(\min )$ & $\mathrm{SC}(\%)$ & $\mathrm{NC}(\%)$ \\
\hline 1 & $\mathrm{DNA}+1+\mathrm{MPA}$ & 40 & - & - & 97 & 3 \\
\hline 2 & $\mathrm{DNA}+2+\mathrm{MPA}$ & 40 & - & - & 27 & 73 \\
\hline 3 & $\mathrm{DNA}+3+\mathrm{MPA}$ & 40 & - & - & 97 & 3 \\
\hline 4 & $\mathrm{DNA}+\mathrm{DMSO}+2+\mathrm{MPA}$ & 40 & - & - & 97 & 3 \\
\hline \multicolumn{7}{|c|}{ Light source: $U V$ transilluminator (96 W total wattage) } \\
\hline 5 & DNA + 1 & 80 & 312 & 10 & 92 & 8 \\
\hline 6 & $\mathrm{DNA}+\mathbf{2}$ & 80 & 312 & 10 & 25 & 75 \\
\hline 7 & $\mathrm{DNA}+\mathbf{3}$ & 80 & 312 & 10 & 82 & 18 \\
\hline 8 & $\mathrm{DNA}+2$ & 50 & 312 & 25 & 1 & 99 \\
\hline \multicolumn{7}{|c|}{ Light source: Mercury vapor lamp (125 W) } \\
\hline 9 & $\mathrm{DNA}+2$ & 80 & 532 & 30 & 29 & 71 \\
\hline 10 & $\mathrm{DNA}+\mathbf{2}$ & 100 & 532 & 30 & 2 & 98 \\
\hline 11 & $\mathrm{DNA}+\mathrm{NaN}_{3}+2$ & 80 & 532 & 30 & 91 & 9 \\
\hline 12 & $\mathrm{DNA}+\mathrm{D}_{2} \mathrm{O}+\mathbf{2}$ & 80 & 532 & 30 & 1 & 99 \\
\hline 13 & $\mathrm{DNA}+\mathrm{DMSO}+2$ & 80 & 532 & 30 & 35 & 65 \\
\hline \multicolumn{7}{|c|}{ Light source: $C W$ laser $(3 \mathrm{~mW})$} \\
\hline 14 & $\mathrm{DNA}+2$ & 100 & 632.8 & 60 & 61 & 39 \\
\hline 15 & $\mathrm{DNA}+\mathbf{2}$ & 100 & 632.8 & 180 & 38 & 62 \\
\hline
\end{tabular}

${ }^{a} \mathrm{SC}$ and $\mathrm{NC}$ are supercoiled and nicked circular forms of DNA, respectively.

(a)

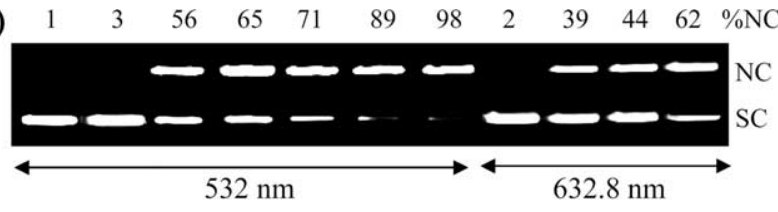

(b)

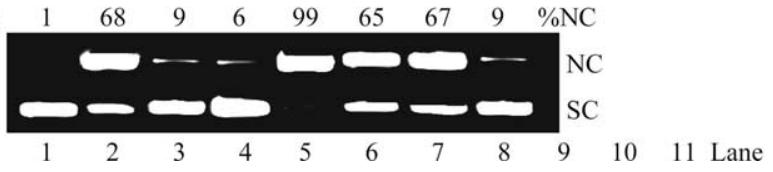

Fig. 5. (a) Photocleavage of SC pUC19 DNA $(0.5 \mu \mathrm{g})$ by 2 using monochromatic radiations of wavelengths 532 ( Hg vapor lamp, 125 W) (lanes 1-7) and 632.8 $\mathrm{nm}$ (3 mW CW laser) (lanes 8-11): lane 1, DNA control (30 min); lane 2, DNA $+2(100 \mu \mathrm{M}$, in dark); lane 3, $\mathrm{DNA}+2(80 \mathrm{M}, 20 \mathrm{~min}) ;$ lane 4 , DNA $+2(80 \mu \mathrm{M}, 30 \mathrm{~min})$; lane 5, $\mathrm{DNA}+2(100 \mu \mathrm{M}, 15 \mathrm{~min})$; lane 6, DNA + $2(100 \mu \mathrm{M}, 20 \mathrm{~min})$; lane 7, DNA + $2(100 \mu \mathrm{M}, 30 \mathrm{~min})$; lane 8 , DNA control $(3 \mathrm{~h})$; lane 9 , DNA + $2(100 \mu \mathrm{M}, 1 \mathrm{~h})$; lane 10 , DNA + $2(100 \mu \mathrm{M}, 2 \mathrm{~h})$; lane 11, DNA $+2(100 \mu \mathrm{M}, 3 \mathrm{~h})$. (b) Cleavage of SC pUC19 DNA $(0.5 \mu \mathrm{g})$ by using different reagents on visible light $(532 \mathrm{~nm}, 125 \mathrm{~W})$ irradiation for $30 \mathrm{~min}$ exposure with a complex concentration of $80 \mu \mathrm{M}$. The reactions were carried out under aerobic conditions except for lane no. 8: lane 1, DNA control; lane 2, DNA + 2; lane 3, DNA+NaN 3 $(100 \mu \mathrm{M})+2 ;$ lane 4 , DNA + L-histidine $(100 \mu \mathrm{M})+2 ;$ lane 5 , $\mathrm{DNA}+\mathrm{D}_{2} \mathrm{O}(14 \mu \mathrm{l})+2$; lane 6 , DNA + DMSO $(2 \mu \mathrm{l})+2 ;$ lane 7 , DNA + mannitol $(2 \mu \mathrm{l})+\mathbf{2}$; lane 8 , DNA + 2 (under argon).

ternary structure, the sulfur containing Schiff base acts as a photosensitizer which on photoactivation forms singlet state which being converted to a longer lifetime triplet state activates oxygen to its cleavage active singlet state $\left({ }^{1} \mathrm{O}_{2}\right)$ in a type-II process.

\section{Conclusions}

Three ternary copper(II) complexes having NSO-donor Schiff bases and NN-donor heterocyclic bases are prepared and structurally characterized by X-ray crystallography. The complexes show distorted square pyramidal $(4+1) \mathrm{CuN}_{3} \mathrm{OS}$ coordination geometry in which the Schiff base binds at the basal plane and the heterocyclic base displays axial-equatorial mode of bonding. The phen complex shows oxidative chemical and photonuclease activity. The role of phen is to bind DNA in the minor groove, while the Schiff base acts as a photosensitizer. The photocleavage reaction involves singlet oxygen as the reactive species.

\section{Supplementary material}

Crystallographic data in the CIF format for 1-3 have been deposited with the Cambridge Crystallographic Data Center, CCDC reference numbers 240179240181, respectively. Copies of this information may be obtained free of charge from The Director, CCDC, 12 Union Road, Cambridge CB2 1EZ, UK (fax: +441223-336-033; e-mail: deposit@ccdc.cam.ac.uk or http://www.ccdc.cam.ac.uk).

\section{Acknowledgments}

We thank the Council of Scientific and Industrial Research (CSIR), New Delhi, and the Department of 
Science and Technology (DST), Government of India, for the financial support; DST for the CCD diffractometer facility; the Alexander von Humboldt Foundation, Germany, for donation of an electroanalytical system; and Professor P.K. Das of our department for the CW laser facility.

\section{References}

[1] B. Meunier, Chem. Rev. 92 (1992) 1411.

[2] G. Pratviel, J. Bernadou, B. Meunier, Angew. Chem. Int. Ed. Engl. 34 (1995) 746.

[3] G. Pratviel, J. Bernadou, B. Meunier, Adv. Inorg. Chem. 45 (1998) 251

[4] J. Reedijk, J. Inorg. Biochem. 86 (2001) 89.

[5] K.E. Erkkila, D.T. Odom, J.K. Barton, Chem. Rev. 99 (1999) 2777.

[6] D.S. Sigman, T.W. Bruce, A. Mazumder, C.L. Sutton, Acc. Chem. Res. 26 (1993) 98.

[7] D.S. Sigman, A. Mazumder, D.M. Perrin, Chem. Rev. 93 (1993) 2295.

[8] S.J. Lippard, Chem. Rev. 99 (1999) 2467.

[9] C.J. Burrows, J.G. Muller, Chem. Rev. 98 (1998) 1109.

[10] B. Armitage, Chem. Rev. 98 (1998) 1171.

[11] W.K. Pogozelski, T.D. Tullius, Chem. Rev. 98 (1998) 1089.

[12] D.R. Mc Millin, K.M. Mc Nett, Chem. Rev. 98 (1998) 1201.

[13] J.A. Cowan, Chem. Rev. 98 (1998) 1067.

[14] E.L. Hegg, J.N. Burstyn, Coord. Chem. Rev. 173 (1998) 133.

[15] L. Changlin, W. Ming, Z. Tianle, S. Hongzhe, Coord. Chem. Rev. 248 (2004) 147.

[16] V. Sharma, D. Piwnica-Worms, Chem. Rev. 99 (1999) 2545.

[17] D.S. Sigman, D.R. Graham, V. D'Aurora, A.M. Stern, J. Biol. Chem. 254 (1979) 12269.

[18] O. Zelenko, J. Gallagher, D.S. Sigman, Angew. Chem. Int. Ed. Engl. 36 (1997) 2776.

[19] M.M. Meijler, O. Zelenko, D.S. Sigman, J. Am. Chem. Soc. 119 (1997) 1135

[20] D.S. Sigman, Biochemistry 29 (1990) 9097.

[21] T.B. Thederahn, M.D. Kuwabara, T.A. Larsen, D.S. Sigman, J. Am. Chem. Soc. 111 (1989) 4941.

[22] H.J. Eppley, S.M. Lato, A.D. Ellington, J.M. Zaleski, Chem. Commun. (1999) 2405.

[23] D.K. Chand, H.-J. Schneider, A. Bencini, A. Bianchi, C. Giorgi, S. Ciattini, B. Valtancoli, Chem. Eur. J. 6 (2000) 4001.

[24] R. Hettich, H.-J. Schneider, J. Am. Chem. Soc. 119 (1997) 5638.

[25] A. Patwardhan, J.A. Cowan, Chem. Commun. (2001) 1490.

[26] L.-P. Lu, M.-L. Zhu, P. Yang, J. Inorg. Biochem. 95 (2003) 31.

[27] A. Garca-Raso, J.J. Fiol, B. Adrover, V. Moreno, I. Mata, E. Espinosa, E. Molins, J. Inorg. Biochem. 95 (2003) 77.

[28] O. Baudoin, M.-P. Teulade-Fichou, J.-P. Vigneron, J.-M. Lehn, Chem. Commun. (1998) 2349.

[29] M. Gonzalez-Alvarez, G. Alzuet, J. Borras, M. Pitie, B. Meunier, J. Biol. Inorg. Chem. 8 (2003) 644.
[30] S. Dhar, D. Senapati, P.K. Das, P. Chattopadhyay, M. Nethaji, A.R. Chakravarty, J. Am. Chem. Soc. 125 (2003) 12118.

[31] S. Dhar, A.R. Chakravarty, Inorg. Chem. 42 (2003) 2483.

[32] A.K. Patra, S. Dhar, A.R. Chakravarty, Chem. Commun. (2003) 1562.

[33] S. Dhar, D. Senapati, P.A.N. Reddy, P.K. Das, A.R. Chakravarty, Chem. Commun. (2003) 2452.

[34] B.K. Santra, P.A.N. Reddy, G. Neelakanta, S. Mahadevan, M. Nethaji, A.R. Chakravarty, J. Inorg. Biochem. 89 (2002) 191.

[35] S. Dhar, P.A.N. Reddy, M. Nethaji, S. Mahadevan, M.K. Saha, A.R. Chakravarty, Inorg. Chem. 41 (2002) 3469.

[36] A.R. Chakravarty, P.A.N. Reddy, B.K. Santra, A.M. Thomas, Proc. Indian Acad. Sci. (Chem. Sci) 114 (2002) 391.

[37] P.A.N. Reddy, B.K. Santra, M. Nethaji, A.R. Chakravarty, Indian J. Chem. 42A (2003) 2185.

[38] P.A.N. Reddy, B.K. Santra, M. Nethaji, A.R. Chakravarty, J. Inorg. Biochem. 98 (2004) 377.

[39] S. Dhar, P.A.N. Reddy, A.R. Chakravarty, Dalton Trans. (2004) 697.

[40] A.M. Thomas, M. Nethaji, A.R. Chakravarty, J. Inorg. Biochem. 98 (2004) 1087.

[41] B.W. Henderson, T.M. Busch, L.A. Vaughan, N.P. Frawley, D Babich, T.A. Sosa, J.D. Zollo, A.S. Dee, M.T. Cooper, D.A. Bellnier, W.R. Greco, A.R. Oseroff, Cancer Res. 60 (2000) 525.

[42] J.L. Sessler, G. Hemmi, T.D. Mody, T. Murai, A. Burrell, S.W. Young, Acc. Chem. Res. 27 (1994) 43.

[43] R. Ackroyd, C. Kelty, N. Brown, M. Reed, Photochem. Photobiol. 74 (2001) 656.

[44] B.W. Henderson, T.J. Dougherty, Photochem. Photobiol. 55 (1992) 145.

[45] E.D. Sternberg, D. Dolphin, C. Brückner, Tetrahedron 54 (1998) 4151

[46] A.M. del C. Batlle, J. Photochem. Photobiol. B. 20 (1993) 5.

[47] M.C. De Rosa, R.J. Crutchley, Coord. Chem. Rev. 233-234 (2002) 351.

[48] R.J. Fiel, N. Datta-Gupta, E.H. Mark, J.C. Howard, Cancer Res. 41 (1981) 3543.

[49] D.D. Perrin, W.L.F. Armarego, D.R. Perrin, Purification of Laboratory Chemicals, Pergamon Press, Oxford, 1980.

[50] O. Kahn, Molecular Magnetism, VCH, New York, 1993.

[51] A.C.T. North, D.C. Phillips, F.S. Mathews, Acta. Crystallogr. A24 (1968) 351.

[52] R.H. Blessing, Acta Crystallogr. A51 (1995) 33.

[53] G.M. Sheldrick, SHELX-97, Programs for Crystal Structure Solution and Refinement, University of Göttingen, Germany, 1997.

[54] C.K. Johnson, ORTEP, Report ORNL-5138, Oak Ridge National Laboratory, Oak Ridge, TN, 1976.

[55] M.E. Reichman, S.A. Rice, C.A. Thomas, P. Doty, J. Am. Chem. Soc. 76 (1954) 3047.

[56] J. Bernadou, G. Pratviel, F. Bennis, M. Girardet, B. Meunier, Biochemistry 28 (1989) 7268.

[57] S. Mahadevan, M. Palaniandavar, Inorg. Chem. 37 (1998) 693.

[58] A.W. Addison, T.N. Rao, J. Reedijk, J.V. Rijn, G.C. Verschoor, J. Chem. Soc., Dalton Trans. (1984) 1349.

[59] M. Lee, A.L. Rhodes, M.D. Wyatt, S. Forrow, J.A. Hartley, Biochemistry 32 (1993) 4237. 